\title{
Erratum to: Feeding ecology of fishes: an overview of worldwide publications
}

\author{
Raul Rennó Braga • Hugo Bornatowski • \\ Jean Ricardo Simões Vitule
}

Published online: 9 November 2012

(C) Springer Science+Business Media Dordrecht 2012

\section{Erratum to: Rev Fish Biol Fisheries DOI 10.1007/s11160-012-9273-7}

Figure 5 has been published incorrectly in the original publication of the article. The correct version of the figure is provided below.

The online version of the original article can be found under doi:10.1007/s11160-012-9273-7.

R. R. Braga · J. R. S. Vitule

Programa de Pós-Graduação em Ecologia e Conservação, Universidade Federal do Paraná, Curitiba, Paraná, Brazil e-mail: raulbraga@onda.com.br

R. R. Braga · H. Bornatowski · J. R. S. Vitule GPIc, Grupo de Pesquisas em Ictiofauna, Museu de História Natural Capão da Imbuia, Curitiba, Paraná, Brazil

e-mail: anequim.bio@gmail.com

H. Bornatowski · J. R. S. Vitule ( $\square)$

Programa de Pós Graduacão em Zoologia, Universidade Federal do Paraná, Curitiba, Paraná, Brazil

e-mail: biovitule@gmail.com

\section{J. R. S. Vitule}

Laboratório de Ecologia e Conservação, Departamento de Engenharia Ambiental, Setor de Tecnologia,

Universidade Federal do Paraná, Curitiba, Paraná, Brazil 
Fig. 5 Correlation between the numbers of species described for each of the thirty most represented countries according to Froese and Pauly (2011) and the number of studies resulting from our search. Countries above the line represent the ones that have, in proportion, a low number of studies when compared to the number of species described, thus being the ones in need of further attention

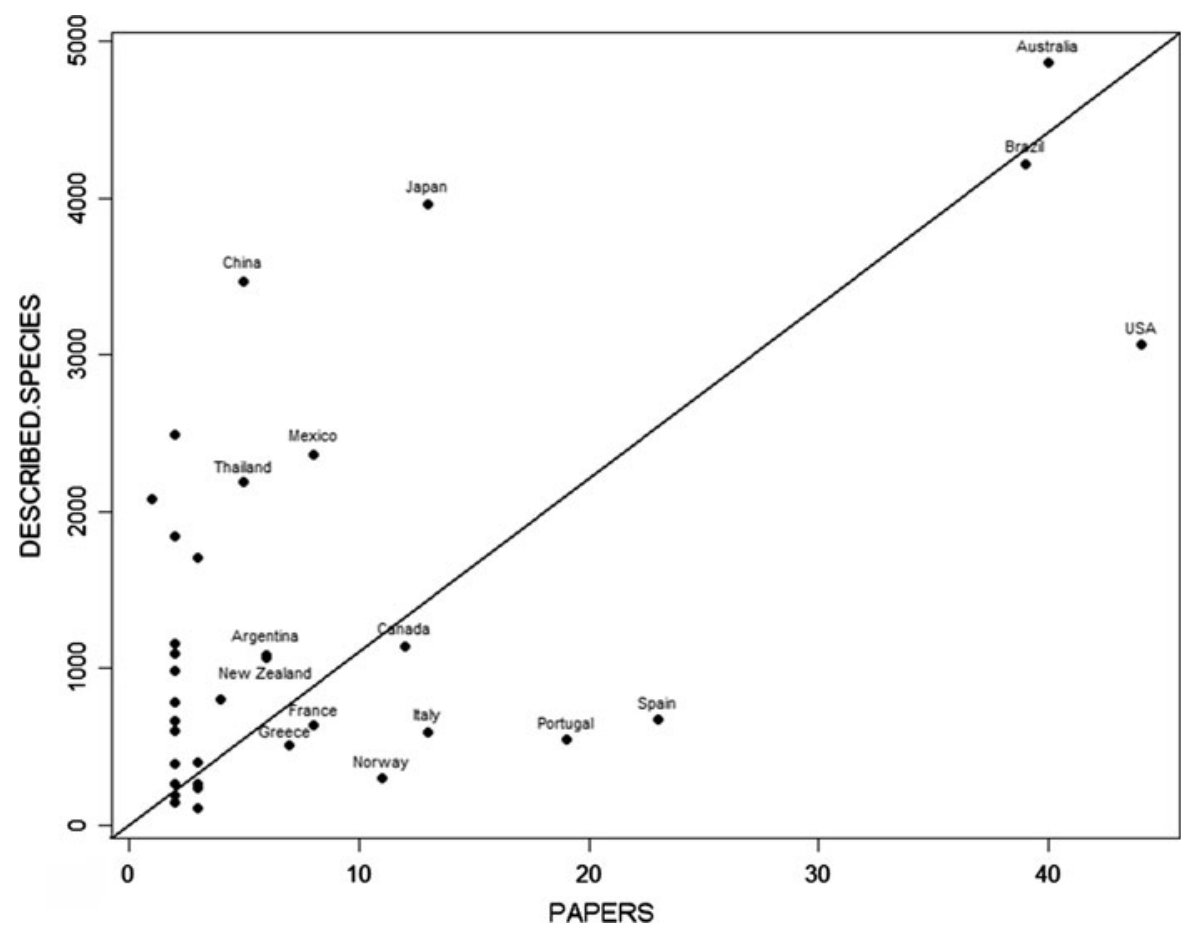

